\title{
Experimental burns: Comparison between silver sulfadiazine and photobiomodulation
}

Mariana Teixeira Gomes ${ }^{1}$, Gabriela Russo Soeiro Campos $^{1}$, Natália Piccolo ${ }^{2}$, Cristiane Miranda França ${ }^{1}$, Guelton Hirano Guedes ${ }^{1}$, Fabio Lopes ${ }^{1}$, Renata A. Belotto ${ }^{1,3}$, Christiane Pavani $^{1}$, Rafael do Nascimento de Lima ${ }^{1}$, Daniela de Fátima Teixeira da Silva ${ }^{1 *}$

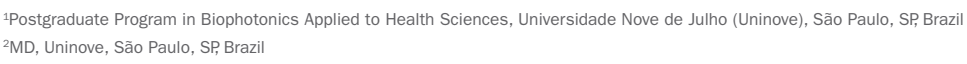

Study conducted at Universidade Nove de Julho (Uninove), São Paulo, SP, Brazil

Article received: $3 / 8 / 2016$ Accepted for publication: 5/2/2016

*Correspondence: Address: Rua Vergueiro, 235 São Paulo, SP - Brazi

Postal code: 01504-001 dfteixeira@uninove.br

http://dx.doi.org/10.1590/1806-9282.63.01.29

\section{SUMMARY}

Objective: To analyze morphological characteristics and organization of the collagen fibers of third degree burns from scalding compared to laser therapy and silver sulfadiazine, the latter considered as the gold standard.

Method: Were selected 12 animals (Rattus norvegicus) also divided into three groups (control group [CG] - untreated burns; sulfadiazine group [SG] - burns were treated with silver sulfadiazine at $1 \%$; laser group [LG] - burns were treated with photobiomodulation). The scald burns were carried out by using PVC mold, and the material collected on the $14^{\text {th }}$ day after burn was prepared for morphological and optical retardation analysis for evaluation of inflammatory infiltrates and collagen organization, respectively.

Results: On the $14^{\text {th }}$ day, the laser and sulfadiazine groups had mild inflammatory response, while the control group showed an intense inflammatory process, with statistical significance between laser and control groups, but not between sulfadiazine and control groups. Laser and sulfadiazine groups no longer had granulation tissue, opposite to what was seen in the control group. The presence of hair follicles and ulcer did not significantly differ between groups. The optical retardation of collagen fibers was higher in sulfadiazine group, followed by laser and control groups. As for systemic effect, we were able to identify it by simply analyzing the presence or absence of granulation tissue.

Conclusion: Morphologically, the laser or silver sulfadiazine treatments were similar and both provided better organization of collagen fibers in relation to the untreated group. However, the sulfadiazine group modulated the deposition of collagen fibers more efficiently than the laser group.

Keywords: burns, scald, sulfadiazine, laser, collagen, rats.

\section{INTRODUCTION}

Burns are a major social and public health problem, given that any person may be subjected to such injury, regardless of age, sex, color or social class. ${ }^{1}$ Burn accidents affect 11 million people worldwide, and these figures refer only to those who have suffered burns severe enough to seek medical attention. ${ }^{2}$ In this type of accident, there is the question of physical and psychological sequelae that may persist in the victim, such as the change of their own image, in addition to social and economic issues, given that it involves the injured patient's reintegration into society, and the high cost of keeping them in hospitals. ${ }^{3,4}$ Burns may be caused by thermal, chemical, electrical or radioactive agents that act on the tissue covering the body, causing lesions that partially or fully affect the skin, and which can reach more internal tissues, such as subcutaneous tissue, muscles, tendons, and bones. ${ }^{5}$ Thermal burns are the most common, with flames and overheated substances as the main agents. ${ }^{6}$ This type of lesion may present in different levels of severity and with a range of complications, making treatment difficult. They can be classified into first degree, second degree and third degree according to their depth of involvement. ${ }^{7}$ The healing of burned skin occurs in the same way as any other injury, following the same steps of repair 
- inflammation, proliferation, and remodeling - and an immature scar may exhibit signs and symptoms that include erythema, progressive elevation in the form of a tumor, edema, pruritus, pain, and blistering. As it matures, the lesion becomes asymptomatic, more malleable, presenting a color close to that of the patient's skin, with better tensile strength. ${ }^{8}$

A recent study involved a review of the literature on treatments offered for dealing with burns in the acute phase, and the topical agents used for the most commonly found dressings were associations of neomycin sulfate and bacitracin, clostebol acetate and neomycin sulfate, and silver sulfadiazine, which is still widely used in Brazil. ${ }^{9}$

Third-degree burns have been a major focus of research and investigation, searching for new treatment methods in order to improve the care of burn patients and also provide greater speed for a satisfactory result without major functional and aesthetic sequelae. ${ }^{10}$ Experimental research conducted on animals have shown that photobiomodulation modulates cellular activity, angiogenesis, synthesis, and collagen deposition, leading to faster closure of the burn and esthetically improved scarring compared to those not treated with photons. ${ }^{11-13}$ The study of the influence of photobiomodulation on the cicatricial process in a scald model using animals will contribute to the search for a treatment that minimizes the physical and psychological sequelae that arise in burn victims. Furthermore, the spending on such victims is expected to decrease, lowering the length of hospitalization and, consequently, reintegrating them more quickly into society.

This is a translational study aimed at comparing burn treatments in an animal model, using the conventional method with $1 \%$ silver sulfadiazine and the alternative method with photobiomodulation. The objective was to analyze the morphological characteristics and organization of the collagen fibers of third degree burns caused by scalding, in relation to laser therapy and to that considered as the gold standard treatment, with the main motivation being the search for a more effective, quicker, and less painful treatment for burn victims.

\section{Method}

Twelve female Rattus novergicus Wistar rats with a body mass between 250 and $300 \mathrm{~g}$ kept in a vivarium at Universidade Nove de Julho (Uninove, São Paulo) were selected. The animals were kept in plastic cages, under ideal hygiene, lighting, and temperature conditions, with standard feed from the vivarium and water ad libitum. The animals were divided randomly and homogeneously into three groups:
CG - control group: the burn was not treated; SG - sulfadiazine group: the burn was subjected to treatment with $1 \%$ silver sulfadiazine; and LG - laser group: the burn was submitted to photobiomodulation.

The burn procedure was performed under general anesthesia with intraperitoneal injection of a solution of ketamine (Dopalen Vetbrands, Jacareí, SP) at a dose of $80 \mathrm{mg} / \mathrm{kg}$ and xylazine (Anasedan Vetbrands, Jacareí, $\mathrm{SP})$ at a dose of $10 \mathrm{mg} / \mathrm{kg}$. After the anesthesia was applied, the animals' backs were trichotomized for realization of the thermal injury via scalding, where four circular regions of the back, with a radius of $0.5 \mathrm{~cm}$ and an area of $0.8 \mathrm{~cm}^{2}$, remained in contact with hot water at $60^{\circ} \mathrm{C}$ for 45 seconds. These areas were delimited by inserting the animal into a mold made of PVC pipe with the same four areas of $0.8 \mathrm{~cm}^{2}$ each, according to the methodology adapted from Cribbs et al..$^{14}$ (Figure $1 \mathrm{~A}$ and $\mathrm{B}$ ).

Thus, each animal had four burns on the back, three of which were treated in the same way according to the experimental group. One of the burns, randomly chosen and standardized between the groups, was kept as the control of that specific animal for verification of the systemic effect of the treatments applied.

After creating the injuries, $1 \%$ silver sulfadiazine (ointment) was applied to SG in a uniform manner and covering the full extent of the lesion. For treatment in the LG, a red diode laser, $\lambda=660 \pm 2 \mathrm{~nm}$, with an output power equal to $5 \mathrm{~mW}$ and a beam area of $0.04 \mathrm{~cm}^{2}$ (Twin Laser, MMOptics, São Carlos, Brazil), was coupled to an optical system in order to obtain an expanded beam $0.8 \mathrm{~cm}^{2}$.

The wound was therefore radiated in a uniform manner (Figure $1 \mathrm{C}$ ). The irradiations occurred on days 0,5 and 12 post-injury, with radiant exposure of $1 \mathrm{~J} / \mathrm{cm}^{2}$ and irradiance of $6.25 \mathrm{~mW} / \mathrm{cm}^{2}$, with 160 seconds of exposure per lesion.

For the morphological analysis, the collected material was stained with hematoxylin and eosin, and the following characteristics were evaluated under transmitted light microscopy with 400x magnification (Carl Zeiss Pol-Interferencial Photomicroscope, Germany): a) inflammatory response, characterized by the presence of polymorphonuclear leukocytes, where a categorization was assigned to each of the following conditions: absent $=0$, mild presence $=1$, moderate presence $=2$ or intense presence $=3 ; b$ ) granulation tissue, characterized by the presence of fibroblasts and neovascularization, and categorized as 0 for absent and 1 for present; $c$ ) presence or absence of hair follicles; d) presence or absence of ulcers.

For analysis of the collagen organization, quantification of birefringence was performed, in nanometers, un- 

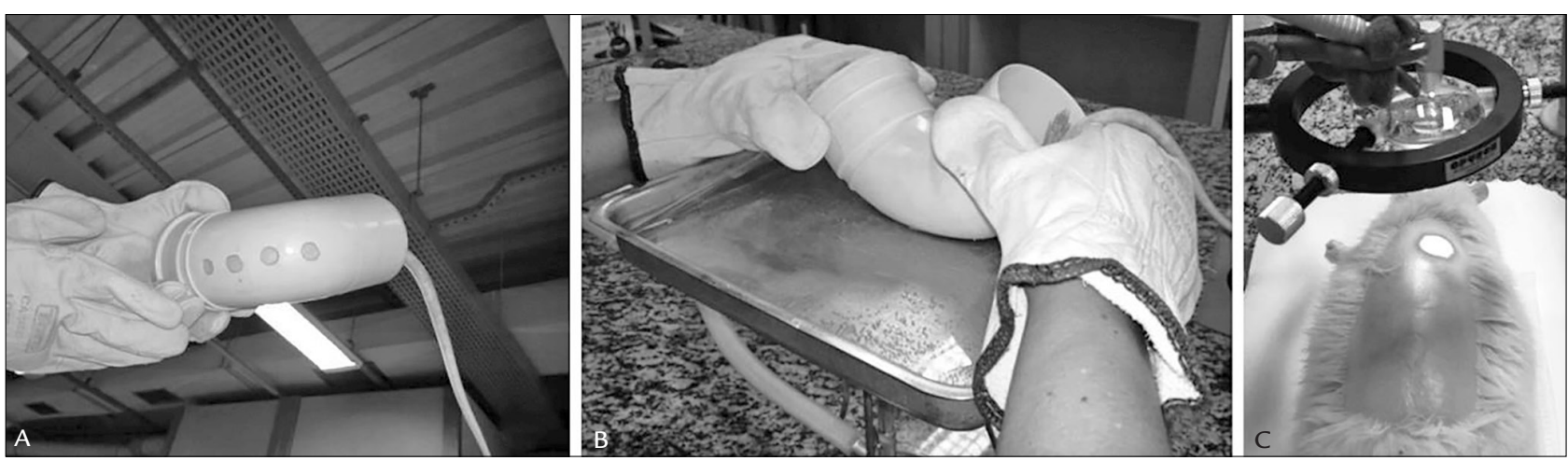

FIGURE 1 A. Mold for the scald. B. Induction of the scald with water at $60^{\circ} \mathrm{C}$. C. Irradiation of lesions.

der a polarized and transmitted light microscope, with magnification of $400 x$, using an interference filter to obtain monochromatic light with $1=546 \mathrm{~nm}$ and compensator that introduces an optical retardation of $1 / 4$ (Carl Zeiss, Pol-Interferencial Photomicroscope, Germany).

The statistical evaluation of the morphology was performed to compare the groups on the $14^{\text {th }}$ day post-burn, using the Chi-square test corrected by Fisher's exact test, with a significance level of $95 \%$. This test is suitable for comparing the frequency of occurrence of an event which, in our case, the frequency of morphological categorizations.

For evaluation of birefringence, the Kruskal-Wallis $\mathrm{H}$ test for nonparametric data was used for the analysis between the groups, followed by the Mann-Whitney U test with a significance level of $95 \%$. All of the analyses were performed using the software Minitab $16^{\circledR}$ (Minitab Inc., USA). All of the analyses were with the data from the $14^{\text {th }}$ day post-burn.

\section{Results}

Table 1 shows the morphological result on day 14 post-induction of the burns.

According to Table 1, CG presented more polymorphonuclear leukocytes, and was categorized as having intense inflammatory activity, unlike LG, which had mild inflammation $(p=0.002)$. However, there was no difference between CG and SG, since SG was characterized by intense (33\% of the samples analyzed) and mild inflammation (67\% of samples analyzed) $(\mathrm{p}=0.059)$, or between $L G$ and SG $(\mathrm{p}=0.450)$. The control lesions of each animal did not respond differently compared to those of the full control group, showing an absence of a systemic effect when leukocytes were evaluated $(\mathrm{p}=0.468)$.

CG presented granulation tissue, unlike LG and SG $(\mathrm{p}=0.002)$. There was a statistically significant difference in relation to granulation tissue on the control injuries of each animal (absent) in relation to those of the full control group (present), indicating a systemic effect ( $\mathrm{p}=0.009$ ).

There were no differences regarding the presence of hair follicles between any of the groups $(\mathrm{p}=0.061)$. The three groups did not present ulcers on this day $(\mathrm{p}=0.182)$. There was no evidence of a systemic effect in these aspects $(\mathrm{p}=0.055)$.

Figure 2 presents the median values of the categorizations for each variable analyzed according to the groups, the analysis of the optical retardation of the collagen fibers, as well as photomicrographs representing each group.

The optical retardation of collagen fibers was greater in SG (24.24 \pm 6.82$)$, followed by LG $(30.30 \pm 6.82)$ and CG $(42.42 \pm 10.60)(\mathrm{p}=0.000)$. There was a significant difference between CG and LG $(\mathrm{p}=0.032)$, as well as between CG and $\mathrm{SG}(\mathrm{p}=0.001)$. LG and SG also differed significantly $(\mathrm{p}=0.004)$.

\section{Discussion}

Our results indicate that on the $14^{\text {th }}$ day the laser group already presented a mild inflammatory response, as well as the $1 \%$ silver sulfadiazine group $(\mathrm{p}=0.450)$, while the control group showed an intense inflammatory process, with statistical significance between LG and CG ( $\mathrm{p}=0.002)$, but not between SG and CG ( $\mathrm{p}=0.059)$. While LG and SG no longer presented granulation tissue on the $14^{\text {th }}$ day, CG was still characterized by the presence of such. The presence of hair follicles did not differ significantly between the groups, although CG did not present follicles and the other groups had $67 \%$ of samples with hair follicles. In addition, significant differences were not detected in relation to the absence of ulcers between the groups.

The optical retardation of collagen fibers was greater in $S G$, followed by LG and CG ( $\mathrm{p}=0.000)$.

As for systemic effect, this could only be identified by analyzing the presence or absence of granulation tissue, as the control burn of each animal in LG and SG pre- 
TABLE 1 Morphological analysis on day 14 post-burn.

\begin{tabular}{lllll} 
Groups & Inflammation & Granulation tissue & Hair follicle & Ulcer \\
\hline CG & Categorization (percentage frequency) & & \\
& Intense & Present & Absent & Absent \\
\hline LG & $(100 \%)$ & $(100 \%)$ & $(100 \%)$ & $(50 \%)$ \\
& Mild & Absent & Present & Absent \\
\hline SG & $(100 \%)$ & $(100 \%)$ & $(67 \%)$ & $(100 \%)$ \\
& Mild & Absent & Present & Absent \\
& $(67 \%)$ & $(100 \%)$ & $(67 \%)$ & $(100 \%)$ \\
\hline
\end{tabular}

CG: untreated control group; LG: photobiomodulation group; SG: silver sulfadiazine group.

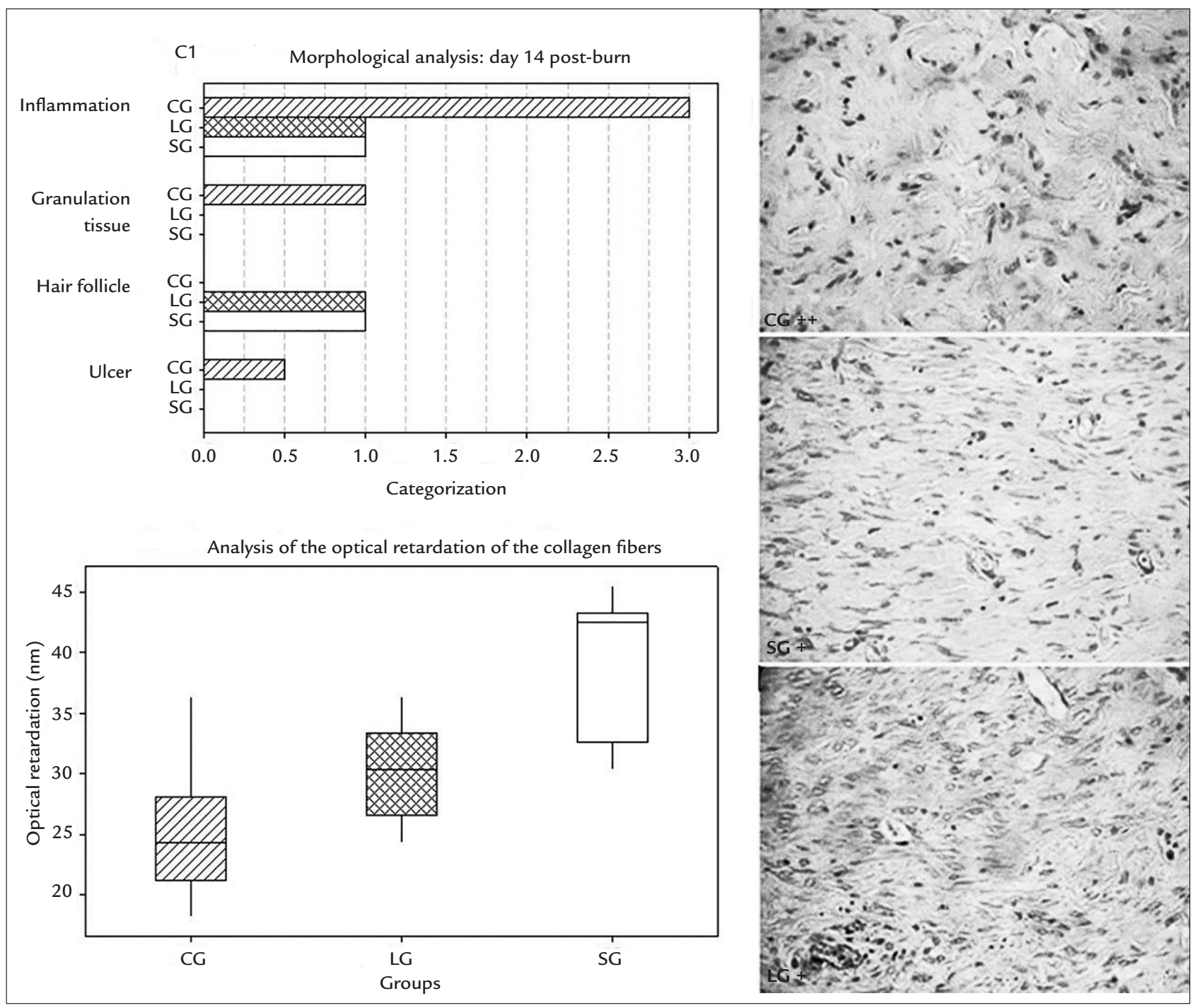

FIGURE 2 Median values of the categorizations attributed to inflammation, granulation tissue, hair follicles and ulceration. In the inferior graph, the horizontal lines from bottom to top represent the $25 \%, 50 \%$ and $75 \%$ of the optical retardation values measured in the samples. The photomicrographs to the right show the control group (CG), with an intense inflammatory process, the silver sulfadiazine group (SG) and the photobiomodulation group (LG) with mild processes. Staining with HE. 400x magnification. 
sented no granulation tissue, while the burns in animals from the full CG still showed the stated tissue ( $p=0.009)$.

In the present study, the $14^{\text {th }}$ day post-burn was chosen for analysis due to the occurrence of collagen deposition, given that after a third-degree burn collagen deposition is expected to be more evident on this day. ${ }^{8}$ In this healing period, ulcers and granulation tissue are ideally absent (they should only be present on the first days of repair) and hair follicles begin to be perceived, with the inflammatory process already concluded or presented in a subtle manner. ${ }^{15}$ Considering these facts, treatment with $1 \%$ silver sulfadiazine and photobiomodulation were shown to be efficient, especially for the laser group, which was the only to present mild inflammation on the day analyzed.

The correlation between optical retardation and collagen arrangement has been explored since the 1960s, , $^{16,17}$ and, to this day, polarizing microscopy is an efficient method for quantifying the change in the birefringence of collagen due to the influence of different agents. ${ }^{18}$ It is important to remember that better organization of collagen fibers implies a better appearance of the scar, as a consequence of a better cicatricial process. ${ }^{8,19}$

With respect to the systemic effect, there is no record of its occurrence in skin lesions using photobiomodulation. However, in this study, it could be observed in the group that was irradiated. A systemic effect of photobiomodulation has been observed when applied to bone tissue, according to the work of Coelho et al. ${ }^{20}$

Another important point to be considered is the dosimetry delivered to the tissue, given that the irradiation parameters were taken from a study that used cold burn instead of scalding. ${ }^{13}$

In burns caused by scalding there is dissipation of the thermal energy through the tissue and the amount of hyalinized collagen is higher in comparison to cold burns. Furthermore, there are important cellular and humoral mediators involved in the pathophysiology of cold burns, as reported in a recent literature review. ${ }^{21}$ Therefore, this scenario is able to change the optical properties of the burned skin, as already verified in the literature. ${ }^{22}$

Thus, the photons may have been so attenuated within the tissue that the radiant exposure of $1 \mathrm{~J} / \mathrm{cm}^{2}$ was not sufficient to accelerate the inflammatory stage of the repair process and, consequently, did not present collagen fibers as organized as the $1 \%$ silver sulfadiazine group.

\section{Conclusion}

Morphologically, the treatments using laser or silver sulfadiazine were similar and both provided greater organization of the collagen fibers compared to the untreated group. However, under the parameters used in this study, SG modulated the deposition of collagen fibers more efficiently than the laser group. There was a systemic effect in the group that received photobiomodulation when the presence of granulation tissue was analyzed.

\section{Resumo}

Queimadura experimental: comparativo entre sulfadiazina de prata e fotobiomodulação

Objetivo: Analisar características morfológicas e organização das fibras colágenas de queimaduras de terceiro grau provocadas por escaldo em relação à terapia com laser e àquela considerada padrão-ouro, a sulfadiazina de prata. Método: Foram selecionados 12 animais (Rattus norvegicus), divididos igualmente em três grupos (grupo controle [GC] - queimaduras não tratadas; grupo sulfadiazina [GS] - queimaduras tratadas com sulfadiazina de prata $1 \%$; grupo laser [GL] - queimaduras tratadas com fotobiomodulação). As queimaduras foram realizadas por escaldo com a utilização de molde de PVC, e o material coletado no $14^{\circ}$ dia pós-queimadura foi preparado para análise morfológica e de retardo óptico, para avaliação do infiltrado inflamatório e da organização do colágeno, respectivamente.

Resultados: No $14^{\circ}$ dia, os grupos laser e sulfadiazina apresentaram resposta inflamatória leve, enquanto o grupo controle apresentou processo inflamatório intenso, havendo significância estatística entre os grupos laser e controle, mas não entre os grupos sulfadiazina e controle. Enquanto os grupos laser e sulfadiazina não apresentavam mais tecido de granulação, o grupo controle ainda apresentava. A presença de folículo piloso e de úlcera não diferiu significantemente entre os grupos. $\mathrm{O}$ retardo óptico das fibras colágenas foi maior no grupo sulfadiazina, seguido dos grupos laser e controle. Apenas a análise da presença ou ausência de tecido de granulação permitiu identificar o efeito sistêmico.

Conclusão: Morfologicamente, os tratamentos com laser ou sulfadiazina de prata foram similares e ambos proporcionaram maior organização das fibras colágenas em relação ao grupo não tratado. Entretanto, o grupo sulfadiazina modulou a deposição das fibras colágenas mais eficientemente que o grupo laser.

Palavras-chave: queimaduras, escaldo, sulfadiazina, laser, colágeno, ratos. 


\section{References}

1. Andrade AG, Lima CF, Albuquerque AK. Efeitos do laser terapêutico no processo de cicatrização das queimaduras: uma revisão bibliográfica. Rev Bras Queimaduras. 2010; 9(1):21-30.

2. Peck MD. Epidemiology of burns throughout the world. Part I: Distribution and risk factors. Burns. 2011; 37(7):1087-1100.

3. Wassermann D. Severity of burn injuries, epidemiology, prevention, french burn care organization. Pathol Biol. 2002; 50(2):65-73.

4. Rahmanian-Schwarz A, Ndhlovu M, Held M, Knoeller T, Ebrahimi B, Schaller HE, et al. Evaluation of two commonly used temporary skin dressings for the treatment of acute partial-thickness wounds in rats. Dermatol Surg. 2012; 38(6):898-904.

5. Prestes M, Júnior S. Gravidade da lesão e indicadores para internação hospitalar. In: Serra M, Maciel E, editors. Tratado de queimaduras. Rio de Janeiro: Atheneu; 2008. p. 49-65.

6. Tavares CS, Hora EC. Caracterização das vítimas de queimaduras em seguimento ambulatorial. Rev Bras Queimaduras. 2011; 10(4):119-23.

7. Gragnani A, Ferreira LM. Pesquisa em queimaduras. Rev Bras Queimaduras. 2009; 8(3):91-6.

8. Piccolo M, Piccolo N, Piccolo M. O processo de cicatrização. In: Serra M, Maciel E, editors. Tratado de queimaduras. Rio de Janeiro: Atheneu; 2004. p. 583-94

9. Rossi LA, Menezez MAJ, Gonçalves N, Ciofi-Silva CL, Farina-Junior JA, Stuch RAG. Cuidados locais com as feridas das queimaduras. Rev Bras Queimaduras. 2010; 9(2):54-9.

10. Prazeres SJ. Tratamento de feridas: teoria e prática. Porto Alegre: Moriá; 2009

11. Ribeiro MS, Silva DF, De Araújo CEN, De Oliveira SF, Pelegrini CMR, Zorn TMT, et al. Effects of low-intensity polarized visible laser radiation on skin burns: a light microscopy study. J Clin Laser Med Surg. 2004; 22(1):59-66.
12. Henriques ACG, Cazal C, Castro JFLD. Ação da laserterapia no processo de proliferação e diferenciação celular. Revisão da literatura. Rev Col Bras Cir. 2010; 37(4):295-302.

13. Núñez SC, França CM, Silva DF, Nogueira GE, Prates RA, Ribeiro MS. The influence of red laser irradiation timeline on burn healing in rats. Lasers Med Sci. 2013; 28(2):633-41.

14. Cribbs RK, Luquette MH, Besner GE. A standardized model of partial thickness scald burns in mice. J Surg Res. 1998; 80(1):69-74.

15. Kumar V, Abbas AK, Fausto N, Aster JC. Robbins \& Cotran Patologia - Bases patológicas das doenças. 8. ed. Rio de Janeiro: Elsevier; 2010.

16. Taylor EW, Cramer W. Birefringence of protein solutions and biological systems. II. Studies on TMV, tropocollagen, and paramyosin. Biophys J. $1963 ; 3: 143-54$

17. Vidal BC, Bozzo L. [Variation of birefringence of the collagen fibers]. Rev Biol Oral. 1966; 4:1-7.

18. Silva DFT, Gomes ASL, de Campos Vidal B, Ribeiro MS. Birefringence and second harmonic generation on tendon collagen following red linearly polarized laser irradiation. Ann Biomed Eng. 2013; 41(4):752-62.

19. Reinke JM, Sorg H. Wound repair and regeneration. Eur Surg Res. 2012; 49(1):35-43.

20. Coelho RCP, Zerbinati LPS, de Oliveira MG, Weber JB. Systemic effects of LLLT on bone repair around PLLA-PGA screws in the rabbit tibia. Lasers Med Sci. 2014; 29(2):703-8.

21. Wright EH, Harris AL, Furniss D. Cooling of burns: mechanisms and models. Burns. 2015; 41(5):882-9.

22. Silva DFT, Ribeiro MS. Light attenuation in rat skin following low level laser therapy on burn healing process. Progress Biomed Opt Imag. 2010; 11:77151O1-6. 